\title{
Effect of yogic practices in State level football players
}

\author{
Dr. Langpoklakpam Tamubi Devi ${ }^{1}$ Nongmaithem Sunderlal Singh ${ }^{2}$ \\ Dr. R. K. Chandrakumar Singh ${ }^{3}$ Dr. Khuraijam Sanatombi Devi ${ }^{4}$ \\ ${ }^{I}$ Research Scholar in Physical Education, Manipur University, India. \\ ${ }^{2}$ Research Scholar in Physical Education, Department of Adult Continuing Education and Extension, Manipur \\ University, India. \\ ${ }^{3}$ Assistant Professor, Department of Physical Education, Health Education \& Sports, D.M. College of Science, \\ Imphal, Manipur. \\ ${ }^{4}$ Assistant Professor, Department of Physical Education, Health Education \& Sports, D.M. College of Science, \\ Imphal, Manipur.
}

\begin{abstract}
To see the effect of three month yogic exercise in state level football players 50 state level football players were selected as a subject. The pre-test, mid test and post test had been taken by using Dynamic flexibility test, side split flexibility test and shoulder and wrist elevation flexibility test tools. To determine the difference between the 3 groups (initial, mid and post test) of state level football players $F$ test was employed at 0.05 significance level. And to determine the training effect the t test for comparison mean was employed for two tails at the confidence level 0.05 level of significant.

The comparative between the initial and post test of dynamic flexibility test, side split flexibility test and shoulder and wrist elevation flexibility test for the state level football players were found to be statistically significant at .05 confidence level as the values 10.676, 10.003 and 10.102 respectively were found greater than the tabulation value (1.98).
\end{abstract}

Key wards: Dynamic flexibility, Side sliding flexibility, shoulder and wrist elevation, F test, comparative t test.

\section{Introduction:}

There are many reasons why Manipuri's are so fond of games and sports since time immemorial. One of the reasons is that the Manipuri's had many indigenous games and sports. Western writers had remarkably recorded about the potentialities, talents, enthusiasm of Manipuri's in sports by young and old alike. People of Manipur are well conducive to certain types of games and sports. The most essential factors of games and sports are strength, flexibility, endurance, speed and body composition etc. an athlete is placed on a stage of triumph if he is well equipped with innate qualities. All these factors are naturally well knitted into the sportspersons of Manipur. He only gap which hinders towards a high degree of performance is the lack of privilege and inadequacy of facilities. Although the improvement is at a snail's pace. It can be improve by concerted efforts that come from various areas.

Among the various games and sports, yoga also takes an important role in the field of games and sports. Therefore, department of youth affairs' and sports, Govt. of Manipur should take appropriate actions for the development of yoga in the state as well as in India. Physical fitness is multidimensional and includes different aspects and also flexibility. Since the early 1900s a battery of test have been developed to assess physical fitness with a view that flexibility is very common \& general characteristics more or less uniform throughout the body. Research study does not substantiate this point. In fact flexibility does not exist as a general characteristic but is specific to a particular joint and joint action ${ }^{1}$. Physiological significance of yogic postures is it gives best organic vigour to the whole body and training the spinal cord and the brain for the interaction of kundalini ${ }^{2}$. An organic vigour is depending upon perfect health of the tissues. A health of the tissues is depending upon three factors: - 1) Constant supply of proper nourishment and of the internal secretion of the endocrine glades. 2) Effective removal of waste products. 3) Healthy functioning of the nerve-connections not only all the physical activities of an individual but also health of the individual depends upon skeletal muscles. No skeletal muscle no physical work is possible. Weak muscles weak health. Yogic postures affect these muscles significantly. In the yogic postures there is ample provision of exercise that would preserve \& promote the health of the muscle of whole body. But as far as strength is concern there is no special provision for it in yogic postures, but muscular strength required for ordinary life can be satisfactorily developed through yogic postures. Amit Gupta, Jaspal Singh, Sandhu and Shyamal Koley ${ }^{3}$ comprised of 95 randomly selected Foot ballers (59 male and 36 female) aged 17-22 years of Indira Gandhi Institute of Physical Education and Sports Sciences Delhi. Another 50 non-athletes subject were taken randomly as a control group from the same area matching their age, socio economic condition etc. with the Foot ballers. There are three fitness test are used for the check of body fitness of Footballers. They are as follows. 1)Sit up test. 2)Board jump test. 3)Shuttle Run. 
The above test are to measure the special mobility and flexibility, three measurements viz anterior spinal flexion, lateral spinal lateral flexion and extension were taken after Macrae and Wight (1969) standard statistical calculation were also made. The results of the present study show highly significant differences between male and female foot bars with there control counter parts in regard to the mobility and flexibility of exhibiting the fact that footballers have greater for mobility and flexibility of spine due to the well structure program of stretching and exercise. All footballers include the stretching Programme in their static programmed in their warm up session too. Footballers keep the muscles more flexible then the controls as the connective tissue around the joint shortens and looses the elasticity when shorter position of activity in case of none sports person. Bhola ${ }^{4}$ selected 25 male volleyball players to study the relationship of absolute leg. length, foot and agility to jumping ability in volleyball using three strides rhythm and fund that the foot length, agility, dynamic power, as well as ankle flexibility had significant relationship with jumping ability using three strides rhythm whereas absolute leg length and relative leg length did not correlate significantly. Singerseth and Haliski ${ }^{5}$ conducted a study the specific purposed of which were (a) to compare the flexibility of 21 joint or areas of football players with the normal college students to compare the flexibility of linesmen and backfield men in the same joints and areas (e) to determine whether there is a difference int he flexibility of comparable right and left joint of the body. Data was obtained from 100 football players. leighton had earlier collected similar data from 56 normal college students. A goviometer called Leigton flenometre was used in taking the flexibility measurements of ankle flexion and extension, knee flexion, leg abduction, lip flexion, and extension trunk hip flexion and extension, ride trunk lip flexion, wrist flexion and extension, arm flexion, elbow flexion, head rotation head extension and flexion and shoulder flexion and extension when right and left sight similar joints of football players were compared. Only the differences between right and left knee flexion and between right and left elbow flexion were large enough to be significant. In non instance was the difference in flexibility between the right and left joint on service course members significant.

Method: for the purpose of the study, 50 state level football players were selected. The players selected for this investigation were freshers in the field of yoga, and they did not know the complete technique of asanas. The yogic practices were given to the players in the morning session for duration of nearly about one hour. 12 asanas excluding shavasana were selected for the investigation. Selections of asanas were done on the bases of shoulder, hip, trunk, wrist joints movements. The investigator want to see the effect of yogic practice on both type of flexibility - the dynamic and static flexibility and also to examine the effect of yogic practices on the few major joints i.e., shoulder, hip and trunk. 1. Side splits test. 2. Shoulder and wrist elevation test. 3. Dynamic flexibility test, were selected as tools to collect the data to judge the degree of flexibility.

To determine the difference between the 3 groups (initial, mid and post test) of state level football players $\mathrm{F}$ test was employed at 0.05 significance level. And to determine the training effect the t test for comparison mean was employed for two tails at the confidence level 0.05 level of significant.

\section{Result:}

\section{Comparison of dynamic flexibility after and before the yogic exercise:}

Table: Comparison of dynamic flexibility in initial, mid and post test among the state level football players:

\begin{tabular}{|c|c|c|c|c|}
\hline & Sum of squares & $\mathrm{df}$ & Mean square & $\mathrm{F}$ \\
\hline Between groups & 164.920 & 2 & 82.460 & $62.858^{*}$ \\
\hline Within groups & 192.840 & 147 & 1.312 & \\
\hline Total & 357.760 & 149 & & \\
\hline
\end{tabular}

$*$ Significant at .05 confidence level. $\mathrm{F}_{.05}=3.06$

The dynamic flexibility test between Initial, mid and post the F value obtain 62.858 is greater than the 3.06 for 2 and 147 degrees of freedom of .05 confidence level. In order to bring out the paired mean differences of the $F$ test Scheffer's post hoc test is employed.

Table: Significant differences between the paired Mean on Dynamic flexibility.

\begin{tabular}{|c|c|c|c|}
\hline \multicolumn{3}{|c|}{ Groups } & Mean difference \\
\hline Initial & Mid & Post & 1.7600 \\
\hline 5.5400 & 7.3000 & & 2.5000 \\
\hline 5.5400 & & 8.0400 & .7400 \\
\hline & 7.3000 & 8.0400 & \\
\hline
\end{tabular}

*Significant at .05 level. $1_{.05}(2,147)=3.38$

It is evident that there is no significant difference existed between initial, mid and post test of the state level football players in dynamic flexibility since the value obtained of critical difference (1) were 1.7600, 2.5000 and .7400 which is less than the critical difference value (3.38) needed to significant for 2 and 147 degrees of freedom, at .05 level. 
Table: experimental group (initial scores and final score) of dynamic flexibility.

\begin{tabular}{|l|l|l|l|l|l|}
\hline Groups & $\mathrm{N}$ & Means & Std. D & Std. Error & M.D \\
\hline Initial scores & 50 & 5.5400 & 1.38814 & .19631 & 2.5 \\
\hline Post scores & 50 & 8.0400 & .90260 & .12765 & \\
\hline
\end{tabular}

Table: comparison of initial scores and final score of dynamic flexibility.

\begin{tabular}{|l|l|c|c|c|c|c|}
\hline \multirow{2}{*}{} & \multicolumn{2}{|c|}{$\begin{array}{c}\text { Levene's for equality of } \\
\text { variance }\end{array}$} & \multicolumn{4}{|c|}{ Test for equality of means } \\
\cline { 2 - 7 } & $\mathrm{F}$ & Sig. & T & df & Sig (2) tailed & Sig SE \\
\hline Equal variances assumed & 9.791 & .002 & $10.676^{*}$ & 98.28 & .000 & .23416 \\
\hline Equal variance not assumed & & & $10.676^{*}$ & 84.150 & .000 & .23416 \\
\hline
\end{tabular}

* Significant at .05 level, ' $t$ ' $.05(98)=1.98$

The comparative between the initial and post test of dynamic flexibility test for the state level football players were found to be statistically significant at .05 confidence level as the value 10.676 was found greater than the tabulation value (1.98).

Comparison of side split test flexibility after and before the yogic exercise:

Table: Comparison of side split test flexibility in initial, mid and post test among the state level football players:

\begin{tabular}{|l|l|l|l|l|}
\hline & Sum of squares & df & Mean square & F \\
\hline Between groups & 576.213 & 2 & 288.107 & $50.772 *$ \\
\hline Within groups & 834.160 & 147 & 5.675 & \\
\hline Total & 1410.373 & 149 & & \\
\hline
\end{tabular}

$*$ Significant at .05 confidence level. $\mathrm{F}_{.05}=3.06$

There was significant difference found among the state level football players on side split flexibility test between Initial, mid and post the F value obtain 50.772 is greater than the 3.06 for 2 and 147 degrees of freedom of .05 confidence level. In order to bring out the paired mean differences of the F test Scheffer's post hoc test is employed.

Table: Significant differences between the paired Mean on side split flexibility test.

\begin{tabular}{|l|l|l|l|}
\hline Groups & Mid & Post & Mean difference \\
\hline Initial & 14.7600 & & 1.6000 \\
\hline 16.3600 & & 11.6400 & $4.7200^{*}$ \\
\hline & 14.3600 & 11.6400 & 3.1200 \\
\hline
\end{tabular}

*Significant at .05 level. $1_{.05}(2,147)=3.38$

It is evident that there is significant difference existed between initial and post test and post test of the state level football players in side split flexibility test since the value obtained of critical difference (1) was 4.7200 which is greater than the critical difference value (3.38) needed to significant for 2 and 147 degrees of freedom, at .05 level. But no significant difference was obtained between initial and mid test and between mid and post test.

Table: experimental group (initial scores and final score) of side split test.

\begin{tabular}{|l|l|l|l|l|l|}
\hline Groups & $\mathrm{N}$ & Means & Std. D & Std. Error & M.D \\
\hline Initial scores & 50 & 16.3600 & 2.43704 & .34465 & 4.7200 \\
\hline Post scores & 50 & 11.6400 & 2.27910 & .32231 & \\
\hline
\end{tabular}

Table: comparison of initial scores and final score of side split test.

\begin{tabular}{|l|l|c|c|c|c|c|}
\hline \multirow{2}{*}{} & \multicolumn{2}{|c|}{$\begin{array}{c}\text { Levene's for equality of } \\
\text { variance }\end{array}$} & \multicolumn{4}{|c|}{ Test for equality of means } \\
\cline { 2 - 7 } & $\mathrm{F}$ & Sig. & $\mathrm{T}$ & $\mathrm{df}$ & Sig (2) tailed & Sig SE \\
\hline Equal variances assumed & 1.509 & .222 & $10.003^{*}$ & 98 & .000 & .47188 \\
\hline Equal variance not assumed & & & $10.003^{*}$ & 97.563 & .000 & .47188 \\
\hline
\end{tabular}

* Significant at .05 level, ' $\mathrm{t}$ ' $.05(98)=1.98$

The comparative between the initial and post test of side split flexibility test for the state level football players were found to be statistically significant at .05 confidence level as the value 10.003 was found greater than the tabulation value (1.98).

Comparison of shoulder and wrist elevation flexibility test after and before the yogic exercise:

Table: Comparison of shoulder and wrist elevation test flexibility in initial, mid and post test among the state level football players:

\begin{tabular}{|l|l|l|l|l|}
\hline & Sum of squares & df & Mean square & F \\
\hline Between groups & 583.570 & 2 & 291.785 & $51.756^{*}$ \\
\hline Within groups & 828.745 & 147 & 5.638 & \\
\hline Total & 1412.315 & 149 & & \\
\hline
\end{tabular}

$*$ Significant at .05 confidence level. $\mathrm{F}_{.05}=3.06$ 
The shoulder and wrist elevation flexibility test between Initial, mid and post the F value obtain 51.756 is greater than the 3.06 for 2 and 147 degrees of freedom of .05 confidence level. In order to bring out the paired mean differences of the F test Scheffer's post hoc test is employed.

Table: Significant differences between the paired Mean on shoulder and wrist elevation flexibility test.

\begin{tabular}{|l|l|l|l|}
\hline Groups & Mid & Most & \\
\hline Initial & Mean difference \\
\hline 11.6400 & 14.7800 & & 3.1400 \\
\hline 11.6400 & & 16.3900 & $4.7500^{*}$ \\
\hline & 14.7800 & 16.3900 & 1.4100 \\
\hline
\end{tabular}

*Significant at .05 level. $1_{.05}(2,147)=3.38$

It is evident that there is significant difference existed between initial and post test of the state level football players in dynamic flexibility since the value obtained of critical difference (1) was 4.7500 which is greater than the critical difference value (3.38) needed to significant for 2 and 147 degrees of freedom, at .05 level.

Table: experimental group (initial scores and final score) of shoulder and wrist elevation test.

\begin{tabular}{|l|l|l|l|l|l|}
\hline Groups & $\mathrm{N}$ & Means & Std. D & Std. Error & M.D \\
\hline Initial scores & 50 & 11.6400 & 2.27910 & .32231 & 4.7500 \\
\hline Post scores & 50 & 16.3900 & 2.42076 & .34235 & \\
\hline
\end{tabular}

Table: comparison of initial scores and final score of shoulder and wrist elevation test.

\begin{tabular}{|l|l|c|c|c|c|c|}
\hline \multirow{2}{*}{} & \multicolumn{2}{|c|}{$\begin{array}{c}\text { Levene's for equality of } \\
\text { variance }\end{array}$} & \multicolumn{4}{c|}{ Test for equality of means } \\
\cline { 2 - 7 } & $\mathrm{F}$ & Sig. & $\mathrm{T}$ & $\mathrm{df}$ & Sig (2) tailed & Sig SE \\
\hline Equal variances assumed & 1.238 & .269 & $10.102^{*}$ & 98 & .000 & .47020 \\
\hline Equal variance not assumed & & & $10.102^{*}$ & 97.646 & .000 & .47020 \\
\hline
\end{tabular}

* Significant at .05 level, ' $t$ ' ${ }_{.05}(98)=1.98$

The comparative between the initial and post test of shoulder and wrist elevation flexibility test for the state level football players were found to be statistically significant at .05 confidence level as the value 10.102 was found greater than the tabulation value (1.98).

\section{Discussion:}

Classification of players on Side-split test flexibility of state level football players

\begin{tabular}{|l|l|l|l|}
\hline Level & Initial & Mid & Post \\
\hline Advance $1 \frac{3}{4}-0$ & & & 1 \\
\hline Advance intermediate $2 \frac{1}{2}-2$ & 1 & & 1 \\
\hline Intermediate $6 \frac{1}{4}-2 \frac{3}{4}$ & 1 & 4 & 1 \\
\hline Advance beginner $9 \frac{1}{4}-6 \frac{1}{2}$ & 2 & 2 & 14 \\
\hline Beginner above $9 \frac{1}{2}$ & 46 & 44 & 33 \\
\hline Total & 50 & 50 & 50 \\
\hline
\end{tabular}

Note: Classifications of players were done as per their norms.

In initial of the training to the state level football players the side split test for flexibility score shows that 46 players are in beginner categories and 2 for advance beginner, 1 for intermediate and I for advance intermediate. After the 6 weeks of training in the mid test out of 50 players, 44 players found beginners, 2 players advance beginner and 4 players in intermediate level. after the 3 months of training in post test 33 players are in beginner, 14 players for advance beginner, 1 for intermediate, 1 for advance intermediate and another 1 found in advance.

Classification of players on shoulder and wrist elevation flexibility test of state level football players

\begin{tabular}{|l|l|l|l|}
\hline Level & Initial & Mid & Post \\
\hline Beginner $6-0$ & & & \\
\hline Advance beginner $8 \frac{1}{2}-6 \frac{1}{4}$ & 3 & & \\
\hline Intermediate $11 \frac{1}{2}-8 \frac{1}{2}$ & 26 & 7 & \\
\hline Advance intermediate $12 \frac{1}{2}-11 \frac{3}{4}$ & 11 & 7 & 2 \\
\hline Advance above $12 \frac{3}{4}$ & 10 & 36 & 48 \\
\hline Total & 50 & 50 & 50 \\
\hline
\end{tabular}

Note: Classifications of players were done as per their norms.

In initial of the training to the state level football players the shoulder and wrist elevation test for flexibility score shows that 3 players are in advance beginner categories and 26 for intermediate, 11 for advance intermediate and 10 in advance. After the 6 weeks of training in the mid test out of 50 players, 7 players found 
intermediate level, 7 players advance intermediate and 48 players in advance level. After the 3 months of training in post test only 2 players are in advance intermediate and remaining 48 are found in advance.

It shows that after three months yogic training programme flexibility improve in the state level football players.

\section{References:}

[1]. Alter M.J., "Science of Flexibility", Human Kinetics, 1999, page 3 \& 4

[2]. Swami Kwalayanada, "Scientific survey of the yogic poses", S MYM Samiti Lonavala 1999 page 2.

[3]. Amit Gupta, jaspal Singh, Sandhu and shyamal koley "A study on the physical Fitness spinal mobility and flexibility.

[4]. Vibha Bhola 'relationship of absolute Leg Length, relative Leg Length, Foot Lentgh, Dynamic power, Ankle Flexibility and agility of jumping Ability to volleyball using three strides Rhythm".

[5]. Peter singerseth and C. Chester Haliski; The flexibility of of football players "Research Quarterly Vol 21 No. 1 (December 1950). PP. 394-398. 